\title{
Model Pembelajaran Bank Street dan Sentra, serta Pengaruhnya terhadap Sosial Emosional Anak
}

\author{
Khadijah $^{\varpi_{1}}$, Arlina $^{2}$, Riska Wahyuni Hardianti ${ }^{3}$, Maisarah $^{4}$ \\ Pendidikan Islam Anak Usia Dini, Universitas Islam Negeri Sumatera Utara \\ DOI: $10.31004 /$ obsesi.v5i2.1054
}

\begin{abstract}
Abstrak
Sosial emosional sangat dibutuhkan agar anak mampu berinteraksi dengan lingkungannya. Observasi di TKIT Nurul Ilmi ditemukan bahwa sosial emosional anak usia 5-6 tahun belum berkembang. Untuk mengembangkan sosial emosional anak diperlukan model pembelajaran yang menyenangkan seperti model pembelajaran bank street dan sentra. Oleh karena itu penelitian bertujuan untuk mengetahui: (1) pengaruh model pembelajaran bank street terhadap sosial emosional; (2) pengaruh model pembelajaran sentra terhadap sosial emosioal; dan (3) perbedaan pengaruh model pembelajaran bank street dan sentra terhadap sosial emosional. Metode penelitian yang digunakan yaitu Quasi Experimental Design dengan sampel sebanyak 38 orang. Instrumen yang digunakan yaitu tes gambar. Teknik analisis data menggunakan uji-t. Hasil penelitian menunjukkan bahwa terdapat perbedaan pengaruh model pembelajaran bank street dan sentra terhadap sosial emosional anak. Dengan menggunakan bank street, anak lebih aktif, kreatif, tercipta interaksi eduakatif, menumbuhkan rasa ingin tahu, dan mendapat respon positif dari anak.
\end{abstract}

Kata Kunci: model pembelajaran bank street; model pembelajaran sentra; sosial emosional; pendidikan anak usia dini

\begin{abstract}
Social-emotional so needed so for children are able to interact with their environment. Observations at TKIT Nurul Ilmi found children's social emotional of aged 5-6 years has not yet developed. To develop children's social emotional needed fun learning model, such as bank street and sentra. Therefore the research aims to determine: (1) influence of bank street learning model towards social emotional; (2) influence of sentra learning model towards social emotional; and (3) differences in influence of bank street and sentra towards social emotional. The research method used Quasi Experimental Design with sample of 38 people. The instrument used is an image test. The data analysis technique used t-test. The results showed that there were differences in influence of bank street and sentra towards children's social emotional. By using bank street, children are more active, creative, create educational interactions, foster curiosity, and get positive responses from children.
\end{abstract}

Keywords: bank street learning model; sentra learning model; social emotional; early childhood education.

Copyright (c) 2021 Khadijah, Arlina, Hardianti, Maisarah

$\triangle$ Corresponding author:

Email Address : khadijah@uinsu.ac.id (Medan, Sumatera Utara, Indonesia)

Received 1 February 2021, Accepted 5 February 2021, Published 9 February 2021 


\section{PENDAHULUAN}

Anak usia dini yang berumur 0-6 tahun yang memiliki pertumbuhan dan perkembangan yang lebih pesat pada awal-awal tahun kehidupannya. Pembelajaran atau pendidikan yang diperlukan anak pada masa ini yaitu untuk membentuk karakter baik pada diri anak. Pembentukan tersebut harus sesuai tahap perkembangan anak. Salah satu perkembangan yang sangat dibutuhkan anak untuk mampu memahami dan berinteraksi dengan lingkungan sekitarnya yaitu aspek perkembangan sosial emosional. Anak yang bahagia dan ceria menjalani hidupnya senantiasa mudah untuk menerima ilmu pengetahuan atau bisa dikatakan anak yang cerdas. Itu sebabnya aspek perkembangan sosial emosional sangat berperan penting di dalam kehidupan anak. Sebagaimana pendapat Martani (2012) dalam hasil penelitiannya bahwa pengembangan emosi pada anak usia dini merupakan hal yang penting karena kalau emosi anak berkembang secara wajar, mereka dapat lebih berkonsentrasi dan mampu menyerap informasi yang diberikan kepada anak dengan lebih baik. Hasil penelitian Nurjannah (2017) mengemukakan bahwa kecerdasan emosional pada anak usia dini ini tidak dimiliki oleh anak secara alami, tetapi harus ditumbuhkan dan dikembangkan oleh orangtua maupun pendidik PAUD dengan mengembangkan aspek sosial dan emosi anak usia dini. Dengan demikian, sosial emosional mempunyai peran penting di dalam kehidupan anak dan membutuhkan proses untuk mengembangkan sosial emosional tersebut.

Menurut Irna (2016), setiap sentra anak akan diarahkan mengenal konsep bagaimana menghargai teman, saling bergantian menggunakan APE dan bahan permainan, bekerja sama membuat suatu karya, dan menunggu giliran dengan sabar. (Ramadhanti et al., 2018) berpendapat bahwa kegiatan anak pada setiap sentra banyak dilakukan dengan kelompok kecil dan memerlukan kerjasama dalam menggunakan alat dan bahan. (Novia \& Mahyuddin, 2020) menambahkan bahwa di dalam pembelajaran, anak dibiasakan untuk menghormati guru dan orang tua serta menyayangi teman dengan cara bekata yang sopan dan baik, serta berperilaku baik dan tidak merugikan orang lain. Oleh karena itu, pembelajaran sentra yang diterapkan di TK IT Nurul Ilmi seharusnya memberikan pengaruh terhadap sosial emosional anak. Namun pada penelitian ini juga diterapkan model pembelajaran bank street sebagai treatment dan pembanding.

Rasulullah juga telah menjelaskan tentang prilaku sosial manusia, diantaranya yaitu: Dari Abu Hurairah radhiyallahu 'anhu, ia berkata, Rasulullah shallallahu 'alaihi wa sallam bersabda:

Setiap persendian manusia diwajibkan untuk bersedakah setiap harinya mulai matahari terbit. Memisahkan (menyelesaikan perkara) antara dua orang (yang berselisih) adalah sedekah. Menolong seseorang naik ke atas kendaraannya atau mengangkat barang-barangnya ke atas kendaraannya adalah sedekah. Berkata yang baik juga termasuk sedekah. Begitu pula setiap langkah berjalan untuk menunaikan shalat adalah sedekah. Serta menyingkirkan suatu rintangan dari jalan adalah shadaqah". (HR. Bukhari dan Muslim di dalam (Baqi, 2017))

Hadis di atas mengisyaratkan bahwa perbuatan sosial yang telah diperbuat dihitung sebagai sedekah didalam agama. Banyak hal sepele menurut manusia, tapi pada hakikatnya mampu menjadikan manusia itu lebih dipandang sebagai manusia karena perilaku sosialnya. Menurut Daniel Goleman dalam Iva Noorlaila (2010) emosi ialah setiap kegiatan atau pengolahan perasaan, pikiran, nafsu, setiap keadaan mental yang hebat dan meluap-luap. Daniel juga mengatakan bahwa emosi merujuk kepada suatu perasaan dan pikiran-pikiran yang khas, suatu keadaan biologis dan psikologis dari serangkaian kecenderungan untuk bertindak. Emosi keluar dengan pengolahan perasaan dan pikiran serta nafsu. Perasaan tersebut berupa ciri khas dari setiap individu yang mengeluarkan emosinya. Contohnya amarah, ada yang mengeluarkan amarah dengan meraung-raung, dan ada juga yang diam saja. Rasulullah mengingatkan umatnya bahwa kekuatan terletak pada kemampuan mengendalikan emosi marah, sebab emosi marah dipengaruhi oleh dorongan hawa nafsu yang tak terkendali. 
Dari Abu Hurairah ra. Dari Rasulullah SAW bersabda: Orang yang kuat itu bukan orang yang kuat berkelahi tetapi orang yang kuat itu ialah orang yang dapat menguasai nafsunya di saat dalam kondisi marah. (Yusuf, 2009)

Perkembangan sosial emosional anak usia dini ditandai dengan adanya perkembangan kemampuan anak untuk beradaptasi dengan lingkungan sekitar, memiliki rasa pertemanan yang melibatkan emosi, pikiran, dan tingkah laku mereka. Aspek perkembangan sosial emosional merupakan salah satu dari aspek perkembangan yang harus dimiliki oleh setiap anak usia dini. Sehingga, untuk melihat adanya pengaruh sosial emosional tersebut dibutuhkan suatu model pembelajaran yang kreatif dan inovatif, tepat dan dapat dengan mudah dipahami oleh anak. Dengan menggunakan model pembelajaran diharapkan dapat berpengaruh dalam proses belajar anak. Pembelajaran tidak akan mencapai hasil yang maksimal jika tidak sedikitpun didukung oleh lingkungan belajarnya yang baik dan suasana yang aman, damai, dan tentram. Guru harus mampu menciptakan kondisi ruang belajar yang menyenangkan, guru juga harus dapat menanamkan pandangan kepada peserta didik bahwa sekolah bukan hanya sebagai tempat yang dapat memberikan beban pada mereka, melainkan sebuah taman bagi mereka untuk belajar. Akan tetapi, perkembangan sosial emosional anak usia dini juga tergantung dari bagaimana orangtua ataupun lingkungan di sekitarnya. Anak usia dini bisa dengan muda bergaul ketika orangtua mereka mengenalkan mereka dan memberikan arahan pada lingkungan sekitar. Dan ada juga yang sosial emosionalnya tidak berkembang karena kemungkinan mereka tidak mendapatkan perkenalan lingkungan di sekitarnya anak yang seperti ini kebanyakan anak yang pendiam dan tertutup.

Dengan demikian, model pembelajaran bank street dan sentra dianggap dapat mengembangkan kemampuan sosial emosional. Penelitian terdahulu mendukung hal tersebut, diantaranya yaitu: penelitian Maryatun \& Hayati (2010) menyimpulkan bahwa Bank Street memiliki komitmen yang tinggi untuk membantu perkembangan anak dengan mengembangkan intelektual dan sosial emosional secara bersamaan. Keduanya penting dalam perkembangan diri anak. Pada penelitian Ika Budi Maryatum, menjelaskan bahwa model pembelajaran bank street memiliki pengembangan keterampilan berfikir juga pengembangan diri, identitas diri, kompetensi, kontrol diri, kemandirian, dan hubungan dengan orang lain. Model pembelajaran bank street membantu anak untuk tidak hanya bersifat individual, tetapi juga mencakup pendidikan kepada masyarakat, termasuk keluarga, sekolah, dan lingkungan yang lebih luas, atau dengan kata lain membina interaksi sosial yang lebih baik pada diri anak. Oleh karena itu, model pembelajaran bank street digunakan pada penelitian ini dengan harapan dapat mempengaruhi sosial emosional anak. Pada penelitian ini juga diterapkan model pembelajaran sentra sebagai pembanding sehingga dianalisis model manakah yang lebih unggul. Pada penelitian ini juga digunakan media yang mendukung penerapan model pembelajaran bank street dan sentra sehingga karakteristik dan prinsip dari kedua model dapat dilaksanakan dengan baik. Pada penelitian ini juga menggunakan model pembelajaran sentra karena model pembelajaran sentra juga tidak kalah bagus dibandingkan model pembelajaran bank street. Bahkan kedua model tersebut menjadikan anak belajar berinteraksi dengan teman sekelasnya sehingga terpatri karakter sosial yang tinggi.

Hasil penelitian Nurwati (2019) membuktikan bahwa setiap sentra memiliki fokus pengembangan aspek kecerdasan dan bila disatukan, semua sentra yang didesain dengan berbagai strategi dalam proses kegiatan pembelajaran dimana anak-anak belajar secara nyata mendorong untuk terlibat langsung dalam pengamatan, berbuat langsung menggunakan media yang ada dengan senang karena tidak terlepas dari konsep bermain anak, semua sentra mengasah kemampuan kecerdasan berpikir logis, intrapersonal, interpersonal, kinestetik, linguistik, naturalis, musikal, visual-spasial dan eksistensial. Sosial emosional anak tergolong ke dalam kecerdasan interpersonal dan intrapersonal sehingga penelitian Nurwati secara tidak langsung membuktikan bahwa bukan sekedar permainan yang dapat mempengaruhi sosial emosional anak tetapi juga penerapan model pembelajaran sentra. Namun untuk lebih 
pastinya, maka pada penelitian ini dilakukan pembaruan atau perbedaan objek yaitu dengan meneliti sosial emosional anak setelah menerapkan model pembelajaran sentra dan dengan menggunakan media atau permainan yang mendukung model tersebut.

Hasil penelitian lain mengenai sentra yaitu Achmadi (2019) yang menyimpulkan bahwa tidak ada pengaruh model pembelajaran BCCT atau sentra terhadap perilaku sosial emosional anak kelompok A di TK Sunan Cendono Kecamatan Kwanyar Kabupaten Bangkalan Madura. Achmadi juga menyarankan kepada semua unsur tenaga terkait dalam dunia pendidikan untuk mempelajari dan memahami model pembelajaran sentra (BCCT) sebab sifat anak yang unik dan memiliki kesenangan bermain, berkumpul sebaya, berimajinatif sangat cocok dikelola secara terbuka bebas, akan tetapi sekolah menerapkannya secara klasikal. Dengan adanya hasil penelitian yang berbeda mengenai keberhasilan pembelajaran sentra dalam mempengaruhi sosial emosional anak, maka dilakukan penelitian ini dengan harapan memberikan solusi yang tepat mengenai pembelajaran mana yang lebih baik dan kiat mencapai perkembangan anak yang optimal. Pada penelitian ini digunakan media atau permainan yang sama pada kedua model pembelajaran (bank street dan sentra). Hal tersebut menjadi perbedaan nyata dan pembaruan penelitian dibandingkan dengan penelitian relevan lainnya.

Dari uraian di atas, maka penelitian ini dilakukan dengan cara menerapkan model pembelajaran bank street dan model pembelajaran sentra pada anak usia 5-6 tahun di TK IT Nurul Ilmi, dan melihat pengaruh dari kedua model tersebut terhadap sosial emosional anak. Dengan demikian, penelitian ini mempunyai tujuan khusus untuk menganalisis pengaruh model pembelajaran bank street dan sentra terhadap sosial emosional anak, dan menganalisis perbedaan pengaruh kedua model tersebut agar diperoleh solusi mengenai model pembelajaran yang lebih unggul dan layak untuk digunakan dalam mengembangkan sosial emosional anak. Tujuan umum dari penelitian ini adalah untuk merekomendasikan model pembelajaran yang lebih baik dan menambah wawasan keilmuan dan kekayaan ilmu intelektual khususnya pada bidang pendidikan anak usia dini. Pendidikan anak usia dini merupakan pondasi terbentuknya karakter yang baik, dan kesiapan pada diri anak untuk memperoleh pembelajaran pada jenjang pendidikan formal.

\section{METODOLOGI}

Penelitian ini dilakukan di TK IT Nurul Ilmi yang beralamat di Jalan Kolam No.1 Komplek Kampus Universitas Medan Area, Kabupaten Deli Serdang, Provinsi Sumatera Utara. Penelitian ini dilaksanakan pada tahun 2020. Jumlah populasi dan sampel pada penelitian sama yaitu sebanyak 38 orang anak usia 5-6 tahun yang aktif di TK IT Nurul Ilmi dan terdistribusi pada dua kelas. Teknik pengambilan sampel pada penelitian ini menggunakan Boring/ Total Sampling. Jenis atau metode penelitian yang digunakan yaitu penelitian kuantitatif dengan desain Quasi Experimental tipe Non-equivalent Control Group Design. Menurut (Maisarah, 2019b) Tipe ini digunakan apabila terdapat dua kelompok sampel yang tidak dipilih secara random, kemudian salah satu kelompok menerapkan sebuah treatment sedangkan kelompok lainnya tidak.

$$
\begin{array}{|lll}
\mathrm{O}_{1} & \mathbf{X} & \mathrm{O}_{2} \\
\hline \mathrm{O}_{3} & \mathrm{O}_{4}
\end{array}
$$

\section{Gambar 1. Metode Penelitian Quasi Experimental tipe Non-Equivalent Control Group Design}

Dari gambar 1 dapat dijelaskan bahwa kelas yang dijadikan sampel pada penelitian ini selanjutnya dinyatakan sebagai kelas ekperimen (diberikan perlakuan dengan insial X pada gambar) dan kelas kontrol (tanpa ada perlakuan khusus). Kelas eksperimen pada penelitian 
ini menerapkan model pembelajaran bank street $(X)$ sedangkan kelas kontrol menggunakan model pembelajaran sentra (yang biasa digunakan di TK IT Nurul Ilmi). Instrumen pengumpulan data yang digunakan pada penelitian ini yaitu lembar observasi dan tes gambar. Kisi-kisi instrumen disajikan pada Tabel 1 dan Tabel 2.

Tabel 1. Kisi-Kisi Tes Sosial Emosional

\begin{tabular}{clcc}
\hline No & \multicolumn{1}{c}{ Deskriptor } & Butir Ke & Jumlah \\
\hline 1. & Berani tampil di depan teman, guru, orang tua dan & 3 & 1 \\
& lingkungan sosial lainnya & 5 & 1 \\
2. & Berani menunjukkan hasil karya & 6 & 1 \\
3. & Ramah dengan teman & 2 & 1 \\
4. & Akrab dengan teman & 7 & 1 \\
5. & Menunggu giliran & 1 & 1 \\
6. & Mendengarkan guru bercerita & 8 & 1 \\
7. & Mandiri mengerjakan tugas & 4 & 1 \\
8. & Bertanggung jawab menyelesaikan tugas dengan tuntas & 9 & 1 \\
9. & Senang menawarkan bantuan pada teman atau guru & 10 & 1 \\
10. & Mendamaikan teman yang bertengkar & 10 & 10 \\
\hline
\end{tabular}

Tabel 2. Kisi-Kisi Lembar Observasi Sosial Emosional

\begin{tabular}{|c|c|c|}
\hline Indikator & Capaian Indikator & Jumlah \\
\hline Kemampuan Percaya Diri & $\begin{array}{l}\text { Berani tampil di depan teman, guru, orang tua } \\
\text { dan lingkungan sosial lainnya. } \\
\text { Berani menunjukkan hasil karya } \\
\text { Ramah dengan teman } \\
\text { Akrab dengan teman }\end{array}$ & 4 \\
\hline $\begin{array}{l}\text { Kemampuan Menenangkan Diri } \\
\text { Kemampuan Penguasaan Diri }\end{array}$ & $\begin{array}{l}\text { Menunggu giliran } \\
\text { Mendengarkan guru bercerita }\end{array}$ & $\begin{array}{l}1 \\
1\end{array}$ \\
\hline Bertanggung Jawab & $\begin{array}{l}\text { Mandiri mengerjakan tugas } \\
\text { Bertanggung jawab menyelesaikan tugas dengan } \\
\text { tuntas }\end{array}$ & 2 \\
\hline $\begin{array}{l}\text { Kemampuan Mengetahui } \\
\text { Lingkungan Sekitar }\end{array}$ & $\begin{array}{l}\text { Senang menawarkan bantuan pada teman atau } \\
\text { guru } \\
\text { Mendamaikan teman yang bertengkar }\end{array}$ & 2 \\
\hline Total & & 10 \\
\hline
\end{tabular}

Berdasarkan gambar 1, maka instrumen penelitian digunakan pada saat sebelum (pretes) dan setelah (postes) perlakuan diterapkan pada setiap kelas. Penggunaan pretes ditandai dengan insial $\mathrm{O}_{1}$ di kelas eksperimen dan $\mathrm{O}_{3}$ di kelas kontrol, sedangkan penggunaan postes ditandai dengan insial $\mathrm{O}_{2}$ di kelas eksperimen dan $\mathrm{O}_{4}$ di kelas kontrol. Setelah data diperoleh maka selanjutnya dilakukan teknik analisis data menggunakan rumus uji-t (Jaya, 2018; Maisarah, 2019c)

\section{HASIL DAN PEMBAHASAN}

Pada kelas eksperimen menggunakan model pembelajaran bank street, sedangkan kelas kontrol menggunakan model pembelajaran sentra. Sosial emosional anak usia 5-6 tahun pada kedua kelas tersebut diukur. Hasil pengukuran sosial emosional menggunakan model pembelajaran bank street dideskripsikan pada tabel 3 dan gambar 2. 
Tabel 3. Hasil Tes Kelas Eksperimen

\begin{tabular}{ccccc}
\hline Skor & Rata-rata & Maksimum & Minimum & Modus \\
\hline Pretes & 18,47 & 27 & 10 & 10 \\
Postes & 31,11 & 46 & 15 & 37 \\
\hline
\end{tabular}

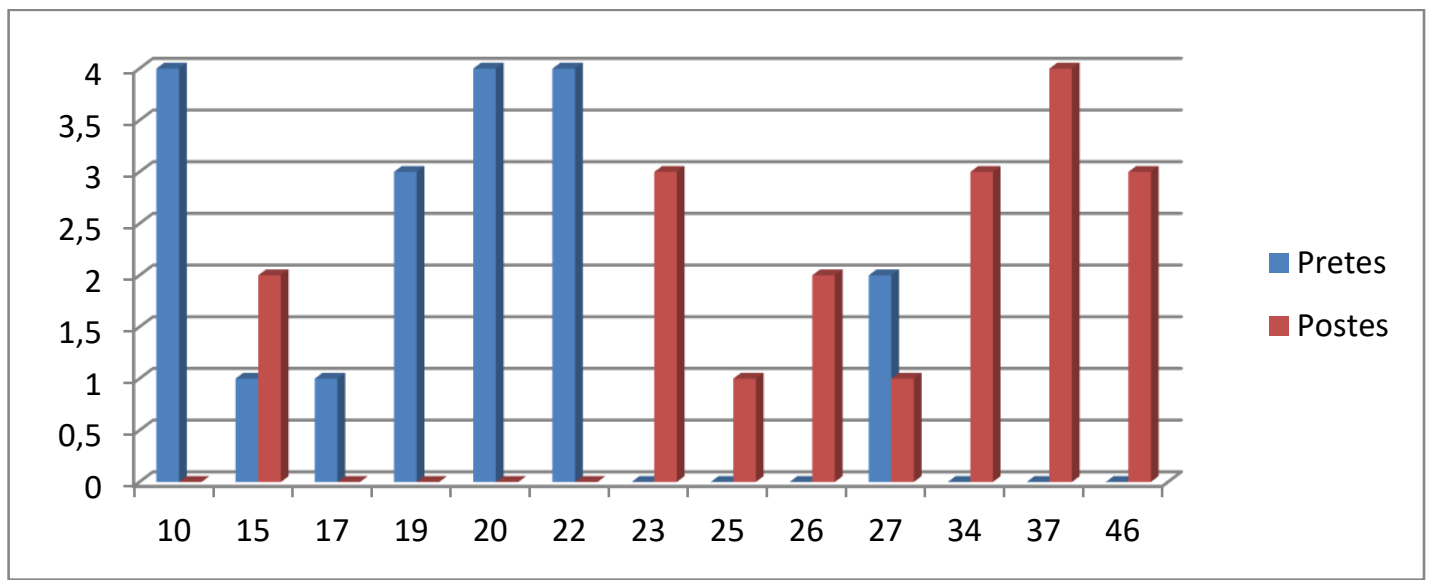

Gambar 2. Hasil Tes Kelas Eksperimen

Tabel 3 dan Gambar 2 menunjukkan bahwa hasil observasi sosial emosional anak usia 5-6 tahun sebelum menggunakan model pembelajaran bank street pretest di kelas eksperimen dengan memperoleh nilai rata-rata 18,47 dengan nilai terendah 10 dan nilai tertinggi 27, dan modusnya 10. Kemudian hasil observasi dengan menggunakan model pembelajaran bank street serta posttest di kelas eksperimen dengan memperoleh rata-rata 31,11 dengan nilai terendah 15 dan nilai tertinggi 46, dan modusnya 37. Hasil pengukuran sosial emosional menggunakan model pembelajaran sentra dideskripsikan pada tabel 4 dan gambar 3 .

Tabel 4. Hasil Tes Kelas Kontrol

\begin{tabular}{ccccc}
\hline Skor & Rata-rata & Maksimum & Minimum & Modus \\
\hline Pretes & 17,63 & 27 & 10 & 10 \\
Postes & 23,42 & 37 & 10 & 29 \\
\hline
\end{tabular}

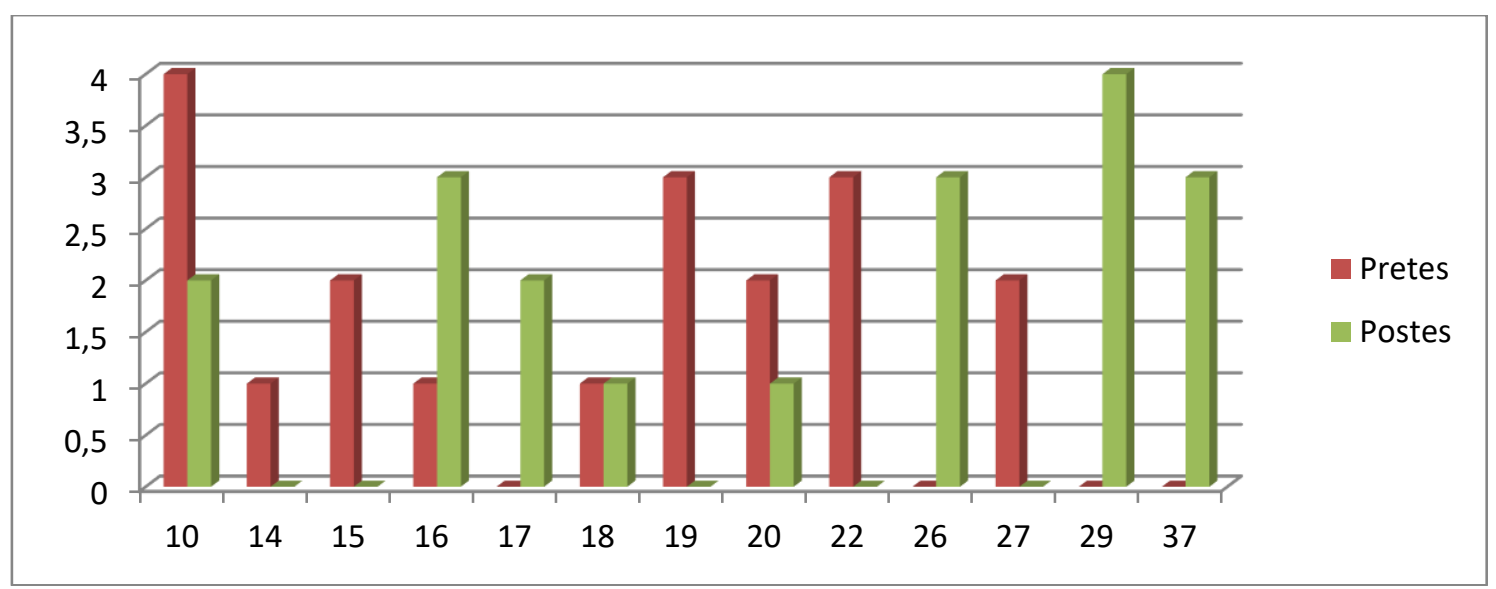

\section{Gambar 3. Hasil Tes Kelas Kontrol}

Tabel 4 dan Gambar 3 menunjukkan bahwa hasil observasi sosial emosional anak usia 5-6 tahun sebelum menggunakan model pembelajaran sentra pada kelas kontrol pre test diperoleh dengan nilai rata-rata 17,63 dengan nilai terendah 10 dan nilai tertinggi 27, dan 
modusnya 10. Kemudian post test pada kelas kontrol dengan menggunakan model pembelajaran sentra diperoleh dengan nilai rata-rata 23,42 dengan nilai terendah 10 dan nilai tertinggi 37, dan modusnya 29. Selanjutnya data sosial emosional di kelas eksperimen dan kontrol diuji menggunakan normalitas yang hasilnya disajikan pada Tabel 5.

Tabel 5. Uji Normalitas Kelas Eksperimen dan Kelas Kontrol

\begin{tabular}{ccccccc}
\hline \multirow{2}{*}{ Kelas } & \multicolumn{3}{c}{ Pre Test } & \multicolumn{3}{c}{ Post Test } \\
\cline { 2 - 7 } Eksperimen & $\mathbf{L}_{\text {hitung }}$ & $\mathbf{L}_{\text {tabel }}$ & Keterangan & $\mathbf{L}_{\text {hitung }}$ & $\mathbf{L}_{\text {tabel }}$ & Keterangan \\
Kontrol & 0,171 & 0,195 & Normal & 0,139 & 0,195 & Normal \\
\hline
\end{tabular}

Tabel 5 menunjukkan bahwa data pre test kelas eksperimen adalah $L_{\text {hitung }}=0,171$ dan $\mathrm{L}_{\text {tabel }}=0,195$ dengan kriteria $\alpha=0,05$. Karena $\mathrm{L}_{\text {hitung }}<\mathrm{L}_{\text {tabel }}$ maka data nilai pretest kelas eksperimen dinyatakan berdistribusi normal. Sedangkan uji normalitas data post test kelas eksperimen adalah $\mathrm{L}_{\text {hitung }}=0,139$ dan $\mathrm{L}_{\text {tabel }}=0,195$ dengan kriteria $\alpha=0,05$. Karena $\mathrm{L}_{\text {hitung }}<$ $\mathrm{L}_{\text {tabel }}$ maka data nilai posttest kelas eksperimen dinyatakan berdistribusi normal. Kemudian pretest kelas kontrol adalah untuk $L_{\text {hitung }}=0,134$ dan $L_{\text {tabel }}=0,195$ dengan kriteria $\alpha=0,05$. Karena Lhitung $<\mathrm{L}_{\text {tabel }}$ maka data nilai pretest kelas kontrol dinyatakan berdistribusi normal. Sedangkan uji normalitas data post test kelas kontrol adalah $L_{\text {hitung }}=0,161$ dan $L_{\text {tabel }}=0,195$ dengan kriteria $\alpha=0,05$. Karena $L_{\text {hitung }}<L_{\text {tabel }}$ maka data nilai posttest kelas eksperimen dinyatakan berdistribusi normal. Selanjutnya data sosial emosional di kelas eksperimen dan kontrol diuji menggunakan homogenitas yang hasilnya disajikan pada Tabel 6 .

Tabel 6. Uji Homogenitas Pretest dan Posttest

\begin{tabular}{cccccc}
\hline Data & Varians Terbesar & Varians Terkecil & $\mathbf{F}_{\text {hitung }}$ & $\mathbf{F}_{\text {tabel }}$ & Keterangan \\
\hline Pre Test & 28,47 & 28,15 & 1,01 & 2,27 & Homogen \\
Post Test & 91,77 & 74,81 & 1,23 & 2,27 & Homogen \\
\hline
\end{tabular}

Tabel 6 menunjukkan bahwa hasil dari hitungan antara pretes dan postes pada kelas eksperimen dan kelas kontrol. Dimana pada pretest didapat $F_{\text {hitung }}=1,01$ dan $F_{\text {tabel }}=2,27$ dengan kriteria $a=0,05$. Karena $F_{\text {hitung }}<F_{\text {tabel }}$ maka data nilai pretest dinyatakan homogen. Begitu juga pada nilai posttest didapat $F_{\text {hitung }}=1,23$ dan $F_{\text {tabel }}=2,27$. Karena $F_{\text {hitung }}<F_{\text {tabel }}$ maka data nilai posttest dinyatakan homogen. Setelah diberi perlakuan yang berbeda antara kelas eksperimen dan kelas kontrol diperoleh nilai pada kelas ekperimen dengan rata-rata 31,11 dan nilai pada kelas kontrol dengan rata-rata 23,42. Dari data yang diperoleh tersebut terdapat perbedaan antara pengaruh model pembelejaran bank street terhadap sosial emosional pada kelas eksperimen dan pengaruh model pembelajaran sentra terhadap sosial emosional pada kelas kontrol.

Hal ini dikarenakan model pembelajaran bank street mendukung anak untuk mengembangkan sosial emosionalnya dengan cara timbal balik dengan masyrakat. Anakanak tau seakan apa yang terjadi di lingkungan sekitarnya akan terjadi pula dalam pembelajarannya sehari-hari. Hasil penerapan model pembelajaran bank street pada kelas eksperimen ternyata cukup memuaskan. Diketahui bahwa sosial emosional anak pada kelas eksperimen yang diberikan perlakuan dengan menggunakan model pembelajaran bank street signifikan dari pada kelas kontrol yang tidak diberikan perlakuan atau pembelajaran yang terjadwal dari sekolah tersebut. Setelah diperoleh perbedaan nilai rata-rata antara kelas ekperimen yang diberikan perlakuan menggunakan model pembelajaran bank street dengan kelas kontrol yang tidak diberi perlakuan menggunakan model pembelajaran bank street nilai range (R), kelas interval (Ci) dan interval dapat disusun distribusi frekuensi data hasil observasi melalui tes gambar pada kelas ekperimen disajikan pada tabel 7: 
Model Pembelajaran Bank Street dan Sentra, serta Pengaruhnya terhadap Sosial Emosional Anak

DOI: $10.31004 /$ obsesi.v5i2.1054

Tabel 7. Sosial Emosional Anak Menggunakan Model Pembelajaran Bank Street

\begin{tabular}{|c|c|c|c|c|c|}
\hline \multirow[t]{2}{*}{ Interval } & \multirow[t]{2}{*}{ Frekuensi } & \multirow{2}{*}{$\begin{array}{c}\text { Persentase } \\
(\%)\end{array}$} & \multicolumn{2}{|c|}{ Kumulatif } & \multirow[t]{2}{*}{ Keterangan } \\
\hline & & & Frekuensi & Persentase $(\%)$ & \\
\hline $10-20$ & 2 & 10,53 & 2 & 10,53 & BB \\
\hline $21-31$ & 7 & 36,84 & 9 & 47,37 & MB \\
\hline $32-42$ & 7 & 36,84 & 16 & 84.21 & BSH \\
\hline $43-53$ & 3 & 15,79 & 19 & 100 & BSB \\
\hline Jumlah & 19 & 100 & & & \\
\hline
\end{tabular}

Tabel 7 menunjukkan bahwa setelah menerapkan model pembelajaran bank street maka diperoleh penilaian sosial emosional anak sebagai berikut: sebanyak 2 dari 19 orang $(10,53 \%)$ anak memperoleh rentang skor terendah yaitu $10-20$ atau mempunyai kategori belum berkembang (BB), sebanyak 7 dari 19 orang (36,84\%) anak memperoleh rentang skor 21-31 atau mempunyai kategori mulai berkembang (MB), jumlah yang sama yaitu sebanyak 7 dari 19 orang $(36,84 \%)$ anak memperoleh rentang skor 32-42 atau mempunyai kategori berkembang sesuai harapan (BSH), dan sebanyak 3 dari 19 orang $(15,79 \%)$ anak memperoleh rentang skor tertinggi yakni 43-53 atau mempunyai kategori berkembang sangat baik (BSB). Data sosial emosional anak yang menggunakan model pembelajaran sentra disajikan pada tabel 8 .

Tabel 8. Sosial Emosional Anak Menggunakan Model Pembelajaran Sentra

\begin{tabular}{cccccc}
\hline Interval & Frekuensi & $\begin{array}{c}\text { Persentase } \\
\mathbf{( \% )}\end{array}$ & Frekuensi & Persentase (\%) & Keterangan \\
\hline $10-20$ & 9 & 47,37 & 9 & 47,37 & BB \\
$21-31$ & 7 & 36,84 & 16 & 84,21 & MB \\
$32-42$ & 3 & 15,79 & 19 & 100 & BSH \\
$43-53$ & 0 & 0 & 19 & 100 & BSB \\
Jumlah & 19 & 100 & & & \\
\hline
\end{tabular}

Tabel 8 menunjukkan bahwa setelah menerapkan model pembelajaran sentra maka diperoleh penilaian sosial emosional anak sebagai berikut: sebanyak 9 dari 19 orang (47,37\%) anak memperoleh rentang skor terendah yaitu 10-20 atau mempunyai kategori belum berkembang (BB), sebanyak 7 dari 19 orang (36,84\%) anak memperoleh rentang skor 21-31 atau mempunyai kategori mulai berkembang (MB), sebanyak 3 dari 19 orang $(15,79 \%)$ anak memperoleh rentang skor 32-42 atau mempunyai kategori berkembang sesuai harapan (BSH), dan tidak ada yang memperoleh rentang skor tertinggi 43-53 atau mempunyai kategori berkembang sangat baik (BSB). Hal ini menunjukkan bahwa sosial emosional dengan menggunakan model pembelajaran bank street lebih baik dibandingkan dengan anak pada kelas kontrol yang menggunakan model pembelajaran sentra. Pada model pembelajaran sentra hanya $15,79 \%$ anak memperoleh tingkat BSH tanpa adanya anak yang mencapai tingkat tertinggi yaitu BSB, sedangkan pada model pembelajaran bank street sebanyak $36,84 \%$ anak memperoleh tingkat BSH dan sebanyak $15,79 \%$ anak mencapai tingkat tertinggi yaitu BSB. Dari data postes sosial emosional anak maka dapat disarankan bahwa model pembelajaran bank street lebih unggul dibandingkan model pembelajaran sentra dalam hal mempengaruhi sosial emosional anak usia 5-6 tahun di TK IT Nurul Ilmi.

Analisis perbedaan skor sosial emosional tersebut tidak dapat dijadikan alasan kuat untuk membuktikan sebuah hipotesa. Oleh karena itu, perhitungan atau uji data dilanjutkan dengan uji hipotesis statistik menggunakan rumus uji-t. Dari pengujian hipotesis menggunakan uji-t diperoleh tiga hasil yakni: (1) pada data kelas eksperimen mempunyai

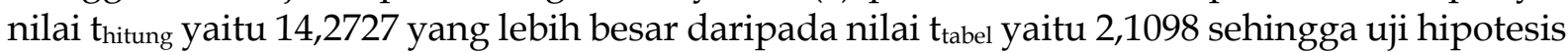
menerima Ha dan menolak $\mathrm{H}_{0}$, maka diperoleh kesimpulan uji bahwa terdapat pengaruh model pembelajaran bank street terhadap sosial emosional anak; (2) pada data kelas kontrol 
mempunyai nilai $t_{\text {hitung }}$ yaitu 6,7498 yang lebih besar daripada nilai $t_{\text {tabel }}$ yaitu 2,0281 sehingga uji hipotesis menerima Ha dan menolak $\mathrm{H}_{0}$, maka diperoleh kesimpulan uji bahwa terdapat pengaruh model pembelajaran sentra terhadap sosial emosional anak; dan (3) data postes dari kedua kelas diperoleh nilai $t_{\text {hitung }}$ yaitu 7,842 yang lebih besar daripada nilai $t_{\text {tabel }}$ yaitu 2,0281 sehingga uji hipotesis menerima Ha dan menolak $\mathrm{H}_{0}$, maka diperoleh kesimpulan uji bahwa terdapat perbedaan pengaruh antara model pembelajaran bank street dan sentra terhadap sosial emosional anak usia 5-6 tahun di TK IT Nurul Ilmi. Perbedaan pengaruh tersebut mengunggulkan model pembelajaran bank street dibandingkan model pembelajaran sentra. Hal tersebut sesuai dengan hasil analisis pemerolehan skor sosial emosional anak di kelas eksperimen lebih tinggi dibandingkan kelas kontrol. Perbedaan tersebut bukan hanya terlihat dari skor yang diperoleh anak tetapi dari hasil dokumentasi penelitian yang disajikan pada Gambar 4-7.

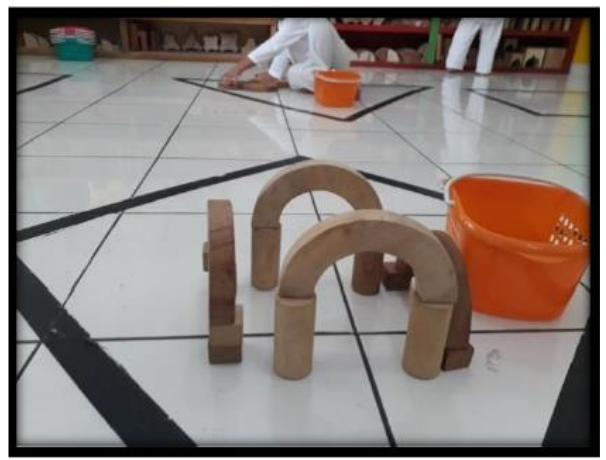

Gambar 4. Proses Pembelajaran di Kelas Kontrol

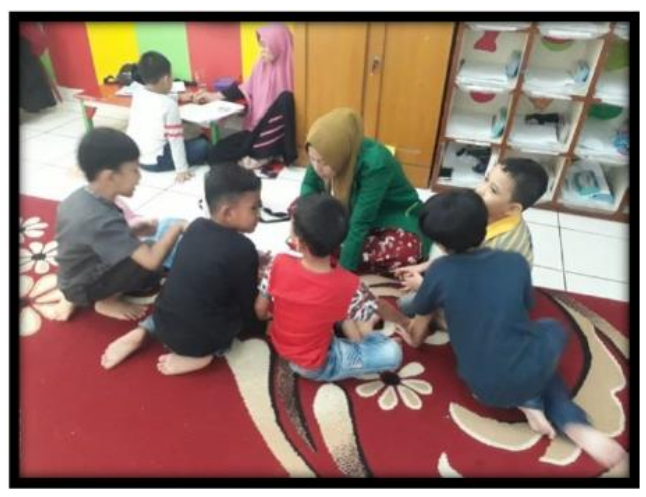

Gambar 6. Anak Mengisi Tes Gambar

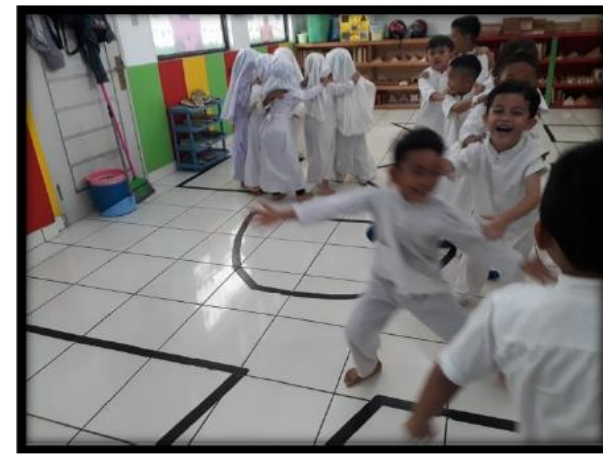

Gambar 5. Proses Pembelajaran di Kelas Eksperimen

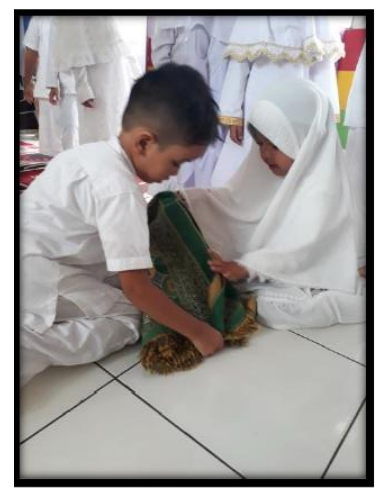

Gambar 7. Anak bekerja sama di Kelas Eksperimen

Dari gambar 4 dan gambar 5 terlihat bahwa model pembelajaran bank street dan sentra menggunakan kegiatan belajar yang mengaktifkan anak menggunakan media tertentu. Dari gambar juga terlihat bahwa anak belajar secara berkelompok baik di kelas ekperimen ataupun kelas kontrol, sehingga akan terjadi interaksi edukatif dan komunikasi aktif antar anak di dalam kelompoknya. Namun pada gambar 5 terlihat anak lebih ceria karena pembelajaran dilakukan dengan permainan yang menimbulkan rasa senang pada anak. Sehingga tercermin bahwa model pembelajaran bank street lebih unggul mempengaruhi sosial emosional anak dibandingkan sentra.

Hasil penelitian Istiqomah et al. (2016) menyimpulkan bahwa melalui kegiatan outbound (permainan halang rintang, estafet tongkat, dan moving water) dapat meningkatkan perkembangan sosial dan emosional pada anak kelompok B TK Asy-Syafa'ah Jember Tahun Pelajaran 2015/2016. Penelitian tersebut senada dengan Mukhlis \& Mbelo 
(2019) bahwa berbagai aspek indikator perkembangan sosial emosional anak terfasilitasi melalui permainan tradisional. Dengan begitu, permainan tradisional dapat menjadi media pembelajaran sosial emosional. Hasil penelitian Ananda \& Fadhilaturrahmi (2018) menyimpulkan bahwa perkembangan sosial emosional dapat dilakukan melalui permainan kolaboratif. Permainan kolaboratif memberikan pengaruh yang cukup besar untuk meningkatkan perkembangan sosial emosional anak. Dari beberapa hasil penelitian terdahulu diperoleh kesimpulan yang mendukung gambar 5 dari hasil penelitian ini bahwa perkembangan sosial emosional anak dipengaruhi dengan menggunakan media atau permainan yang mendukung penerapan model pembelajaran. Dengan kata lain, model pembelajaran dan media atau pemainan saling berkaitan dalam mempengaruhi perkembangan anak.

Selanjutnya pada gambar 7 menunjukkan sikap kerja sama anak di kelas eksperimen dalam mengerjakan arahan dari gurunya. Pada gambar 4 terlihat bahwa anak dibimbing oleh guru dan peneliti untuk mengerjakan tes gambar. Dari gambar tersebut, anak mengerjakan tes dengan perasaan senang, bahkan seperti tidak sedang ujian atau sedang dilakukan penilaian terhadap kemampuan sosial emosional anak. Hal tersebut merupakan salah satu cara guru dapat menilai dan mengamati perkembangan anak secara akurat, baik menggunakan guru tersebut menggunakan model pembelajaran bank street, sentra ataupun model lainnya.

Perbedaan pengaruh yang diberikan kedua model pembelajaran tersebut didasarkan pada kelebihan dan prinsip model pembelajaran bank street yang tidak dimiliki oleh model pembelajaran sentra. Menurut (Mutiah, 2010) terdapat tiga hal penting dalam model pembelajaran bank street, yaitu: pertama, model pembelajaran bank street merupakan model pembelajaran dimana anak merupakan pembelajar, pencoba, penjelajah, dan aktif. Pembelajaran bank street tidak mengharapkan anak menerima pembelajaran saja, tetapi yang diutamakan adalah proses mencari dan menekankan sendiri materi pembelajaran yang didapat dari pengalaman sehari-hari. Hal penting yang kedua sejalan dengan pendapat (Yus, 2015) bahwa model pembelajaran bank street adalah pendidikan yang berorientasi agar anak menjadi seorang pembelajar abadi. Artinya sesuatu yang dilakukan pada keseharian di lingkungan dan materi yang dipelajari akan bermakna fungsional dan tertanam erat dalam memori anak sehingga tidak akan mudah terlupakan.

Model pembelajaran bank street memberikan pengalaman belajar secara nyata kepada anak sehingga anak mampu menggali pengetahuannya sendiri. Penerapan model pembelajaran bank street pada penelitian ini memperoleh respon positif dari anak-anak ketika proses pembelajaran berlangsung, anak tidak lagi menjadi penerima informasi yang bersifat pasif sebagai pendengar. Anak menjadi lebih aktif, kreatif, mampu berintegrasi dengan teman, mampu bekerja sama, anak dapat mencari tahu pengetahuannya sendiri, bereksplorasi dan tetap melakukan interaksi edukatif bersama teman dan gurunya. Sebagaimana pendapat Dewi et al. (2020); Maisarah (2019a) bahwa kemampuan bersosialisasi dan kematangan emosi anak tidak terjadi dengan sendirinya, akan tetapi membutuhkan kesempatan, pengalaman dan peran dari orang tua, guru, teman sebaya bahkan orang dewasa di sekitar anak sebagai scaffolding.

Lucy Sprague Mitchell, Caroline Pratt, dan Harriet Johnson dalam Maryatun \& Hayati (2010) sebagai pencetus pembelajaran bank street yang berawal dari Nursery School mengemukakan pendapatnya bahwa kekuatan pendidikan yaitu untuk mempengaruhi dan meningkatkan masyarakat. Hal tersebut berdasarkan hasil analisis dan persetujuannya dengan pandangan John Dewey mengenai pendidikan. Menurut Rusman (2014) model pembelajaran bank street juga mendorong perkembangan anak secara keseluruhan untuk bertanggung jawab dengan dirinya sendiri, keluarga, dan masyarakat, mengambangkan motivasi untuk kemampuan yang dimiliki, mengambangkan rasa berinteraksi sosial dan kepedulian dengan lingkungan, serta mendorong kreativitas. Dengan demikian, penerapan 
bank street diharapkan dapat menjadikan anak sebagai pembelajar aktif, peneliti atau eksplorer, menjalin interaksi edukatif, dan mampu mengontrol emosinya dengan baik.

Penelitian Darling-Hammond et al. (2002) mengungkapkan bahwa Bank Street has aimed to develop child-centered education grounded in knowledge of human development and focused on preparing students for critical thinking and social responsibility, yang artinya bahwa Bank Street mempunyai tujuan untuk mengembangkan pendidikan dasar yang berpusat pada siswa di dalam pengetahuan dan fokus dalam mempersiapkan siswa untuk berfikir kritis dan respon sosial. Nuraeni (2014) menyimpulkan hasil penelitiannya bahwa prinsip-prinsip pembelajaran PAUD adalah berorientasi pada tujuan, aktivitas, individualitas, integritas, interaktif, inspiratif, menyenangkan, menantang, dan motivasi. Model pembelajaran yang berpusat pada anak dan mendukung prinsip tersebut yaitu: Montessori, Bank Street, High-Scope, Kurikulum Kreatif, dan Regio Emillia. Dengan demikian model pembelajaran Bank Street dianggap lebih mengaktifkan anak dibandingkan dengan model pembelajaran Sentra karena penelitian Nuraeni tidak menyebutkan bahwa sentra tergolong di dalamnya.

Penelitian Grinberg \& Goldfarb (2015) menyimpulkan bahwa Students at Bank Street developed a sense of relationship between the need to understand and influence the social context of their future students and how to foster and advance social justice. yang artinya bahwa anak yang menggunakan pembelajaran Bank Street akan mengembangkan hubungan antara kebutuhan memahami sesuatu dengan pengaruh konteks sosial di masa depan dan cara untuk mendukung keadilan sosial di lingkungan mereka. Penelitian ini membuktikan mengenai kebermaknaan materi yang dipahami anak dan kaitannya dengan kehidupan sosialnya, sehingga pembelajaran Bank Street juga mempengaruhi konteks sosial atau pada anak usia dini berkaitan dengan aspek perkembangan sosial emosional anak.

Uraian di atas membuktikan bahwa model pembelajaran bank street layak dan direkomendasikan kepada pada guru untuk menerapkannya dalam proses pembelajaran, khususnya pada anak usia dini. Menurut Suryana (2014), anak dibimbing agar mampu memahami berbagai hal tentang yang perlu anak ketahui di lingkungan anak usia dini sesuai kurikulum 2013. Hal tersebut bermakna bahwa pendidikan anak usia dini bertujuan untuk mengembangkan beberapa aspek pada anak secara utuh dan keseluruhan nemun tetap mengikuti petunjuk pembelajaran yang tertera pada kurikulum 2013. Model pembelajaran bank street dapat mencapai tujuan tersebut dengan cara mengaplikasikan kognitif melalui kegiatan eksplorasi yang tujuan akhirnya membentuk karakter atau sosial emosional anak yang baik. Dari uraian pembahasan tersebut membuktikan bahwa model pembelajaran bank street terbukti memberikan pengaruh yang signifikan terhadap sosial emosional anak usia 56 tahun di TK IT Nurul Ilmi.

Hasil penelitian ini diharapkan dapat memberikan kontribusi nyata bagi kemajuan pengetahuan, khususnya pada proses dan hasil pendidikan anak usia dini. Karena sejatinya, proses pembelajaran pada ranah pendidikan anak usia dini mempunyai tujuan untuk membentuk karakter yang baik pada diri anak, mempersiapkan seluruh aspek perkembangan anak agar mempunyai kesiapan menempuh pendidikan formal yang lebih tinggi, serta menjadikan anak senang untuk belajar dan selalu ingin belajar. Jika sedari dini anak sudah senang untuk belajar dan belajar secara langsung bersama dengan temannya, maka akan tercipta empat pilar pendidikan menurut UNESCO (learning to know, learning to do, learning to $b e$, dan learning to live together). Seperti halnya penerapan model pembelajaran bank street dan sentra pada penelitian ini, anak belajar untuk mengetahui materi yang diajarkan (learning to know), anak melakukan praktek langsung (learning to do), anak belajar menjadi pemimpin ketika diberikan tugas untuk memimpin tim (learning to be), dan anak berinteraksi dengan temannya untuk menyelesaikan tugas permainan dengan baik (learning to live together).

Namun pada penelitian ini ditemukan beberapa keterbatasan yang dialami, diantaranya yaitu: waktu penelitian terbatas sehingga data post-tes yang diambil hanya satu kali, hasil dokumentasi berbentuk foto yang kurang rinci sehingga kegiatan pada model pembelajaran bank street ataupun sentra tidak dapat dianalisis dan diuraikan secara jelas, 
model pembelajaran bank street merupakan model yang baru pertama kali digunakan di sekolah tersebut ketika penelitian ini berlangsung sehingga besar kemungkinan penerapan model tersebut belum semaksimal mungkin atau belum sesuai teori yang sebenarnya, dan peneliti bukanlah guru yang bertugas di sekolah tersebut sehingga beberapa anak mungkin belum menunjukkan sifat atau sikap yang seperti biasanya. Beberapa keterbatasan yang dialami peneliti mungkin berpengaruh terhadap hasil penelitian, baik itu hasil analisis di kelas yang menggunakan model pembelajaran bank street ataupun di kelas yang menggunakan model pembelajaran sentra. Jika objek pada penelitian ini dikaji pada subjek dan lokasi yang berbeda, maka besar harapan peneliti agar keterbatasan yang dialami tidak diulangi. Sehingga hasil kajian atau riset yang selanjutnya memberikan kontribusi yang lebih nyata dirasakan dalam hal kemajuan ilmu pengetahuan. Adapun kelebihan atau keunggulan dari hasil penelitian ini yaitu: (1) pada penelitian ini dianalisis pengaruh dari penerapan dua model pembelajaran (bank street dan sentra) terhadap sosial emosional anak, bahkan pada penelitian ini diteliti manakah model pembelajaran yang lebih unggul dan disarankan untuk diterapkan; dan (2) pada penelitian ini juga digunakan media dan permainan yang mendukung pembelajaran, karena sejatinya setiap model pembelajaran membutuhkan media atau kegiatan yang mendukung agar karakteristik model pembelajaran dapat muncul, dan hal ini menjadi keunggulan dari penelitian ini sekaligus menjadi saran kepada peneliti lainnya agar tidak memisahkan keduanya.

\section{SIMPULAN}

Sosial emosional anak yang menerapkan model pembelajaran bank street lebih baik dibandingkan sentra. Model pembelajaran bank street sangat direkomendasikan untuk diterapkan pada proses pembelajaran, khususnya untuk meningkatkan sosial emosional anak. Hasil pada penelitian ini menyarankan agar guru atau pemerhati pendidikan anak usia dini untuk memperhatikan karakter dan sosial emosional anak ketika proses pembelajaran berlangsung, hal tersebut karena anak akan mampu mengikuti pembelajaran dengan baik jika kondisi hati dan psikisnya juga baik, itu sebabnya dibutuhkan model pembelajaran yang bukan sekedar memberikan pengetahuan dan melatih keterampilan tetapi juga menumbuhkan rasa senang dan mematri karakter baik pada diri anak sebagaimana model pembelajaran bank street.

\section{UCAPAN TERIMA KASIH}

Penulis mengucapkan terima kasih kepada kepada semua pihak yang telah membantu melaksanakan penelitian dan penulisan artikel ini. Secara khusus, penulis mengucapkan terima kasih kepada kepada sekolah TKIT Nurul Ilmi karena telah mengizinkan penulis untuk melakukan penelitian, kepada guru TKIT Nurul Ilmi yang membantu penulis melakukan penelitian, dan kepada siswa TKIT Nurul Ilmi yang menjadi subjek penelitian karena mempunyai respon yang positif dan mendukung penelitian. Penelitian ini dibiayai oleh penulis secara pribadi, dan artikel ini diangkat dari hasil penelitian skripsi Riska Wahyuni Hardianti jurusan PIAUD Universitas Islam Negeri Sumatera Utara Medan.

\section{DAFTAR PUSTAKA}

Achmadi. (2019). Model Pembelajaran Sentra dapat Mengembangkan Sikap Bersosial untuk Anak Usia Taman Kanak-Kanak. Incrementapedia: Jurnal Pendidikan Anak Usia Dini, 1(2).

Ananda, R., \& Fadhilaturrahmi, F. (2018). Peningkatan Kemampuan Sosial Emosional Melalui Permainan Kolaboratif pada Anak KB. Jurnal Obsesi: Jurnal Pendidikan Anak Usia Dini, 2(1), 20-26. https:// doi.org/10.31004/obsesi.v2i1.3

Baqi, M. F. A. (2017). Shahih Bukhari Muslim Terjemahan Muhammad Ahsan bin Usman. Jakarta: Elex Media Komputindo Kompas.

Darling-Hammond, L., Chung, R., \& Frelow, F. (2002). Variation in teacher preparation: How 
well do different pathways prepare teachers to teach? In Journal of Teacher Education (Vol. 53, Nomor 4, hal. 286-302). https:// doi.org/10.1177/0022487102053004002

Dewi, A. R. T., Mayasarokh, M., \& Gustiana, E. (2020). Perilaku Sosial Emosional Anak Usia Dini. Jurnal Golden Age, 4(1).

Grinberg, P. J., \& Goldfarb, P. K. P. (2015). Learning to Teach for Social Justice: Context and Progressivism at Bank Street in the 1930's. Journal of Education and Human Development, 4(2). https://doi.org/10.15640/jehd.v4n2a6

Irna. (2016). Implementasi kecerdasan jamak (multiple intelegences) pada model pembelajaran bect atau sentra pendidikan anak usia dini. Jurnal Kajian Pendidikan Dan Sosial Kemasyarakatan, 9(2).

Istiqomah, N., Lathif, M. A., \& Khutobah, K. (2016). Peningkatan Perkembangan Sosial dan Emosional Melalui Kegiatan Outbound pada Anak Kelompok B di TK Asy-Syafa'ah Jember Tahun Pelajaran 2015/2016. Jurnal Edukasi, 3(2), 19. https:// doi.org/10.19184/jukasi.v3i2.3524

Iva Noorlaila. (2010). Panduan lengkap mengajar PAUD. Yogyakarta: Pinus Book Publisher.

Jaya, I. (2018). Penerapan Statistik Untuk Pendidikan. Medan: Perdana Publishing.

Maisarah. (2019a). Matematika dan Sains Anak Usia Dini (Edisi Revisi). Medan: Akasha Sakti.

Maisarah. (2019b). Metode Penelitian Pendidikan Pendekatan Kuantitatif. Medan: Akasha Sakti.

Maisarah. (2019c). Statistik Pendidikan. In Akasha Sakti: Medan.

Martani, W. (2012). Metode Stimulasi dari Perkembangan Emosi Anak Usia Dini. Jurnal Psikologi, 39(1).

Maryatun, I. Bu., \& Hayati, N. (2010). Pengembangan Program Pendidikan Anak Usia Dini. Universitas Negeri Yogyakarta.

Mukhlis, A., \& Mbelo, F. H. (2019). Analisis Perkembangan Sosial Emosional Anak Usia Dini pada Permainan Tradisional. Preschool (Jurnal Perkembangan dan Pendidikan Anak Usia Dini, 1(1), 11-28. http://ejournal.uinmalang.ac.id/index.php/preschool/article/view/8172

Mutiah, D. (2010). Psikologi Bermain Anak Usia Dini. Jakarta: Kencana Prenada Media Group.

Novia, A. P., \& Mahyuddin, N. (2020). Pembelajaran Sentra dalam Mengembangkan Kecerdasan Interpersonal Anak. Jurnal Pendidikan Tambusai, 4(2), 1247-1255.

Nuraeni, N. (2014). STRATEGI PEMBELAJARAN UNTUK ANAK USIA DINI. Prisma Sains: Jurnal Pengkajian Ilmu dan Pembelajaran Matematika dan IPA IKIP Mataram, 2(2), 143. https:// doi.org/10.33394/j-ps.v2i2.1069

Nurjannah. (2017). Mengembangkan Kecerdasan Sosial Emosional Anak Usia Dini Melalui Keteladanan. HISBAH: Jurnal Bimbingan Konseling dan Dakwah Islam, 14(1).

Nurwati, N. (2019). Penerapan Model Pembelajaran Berbasis Sentra dalam Mengembangkan Kecerdasan Jamak di Taman Kanak-Kanak Kota Samarinda. Southeast Asian Journal of Islamic Education, 2(1), 15-31. https://doi.org/10.21093/sajie.v2i1.1860

Ramadhanti, M., Sumantri, M. S., \& Edwita, E. (2018). Pembelajaran Sentra dalam Membangun Kecerdasan Jamak di Sekolah Dasar. Journal of Elementary School (JOES), 1(1), 9-21. https:// doi.org/10.31539/joes.v1i1.168

Rusman. (2014). Model-model Pembelajaran. Jakarta: Raja Grafindo Persada.

Suryana, D. (2014). Kurikulum Pendidikan Anak Usia Dini Berbasis Perkembangan Anak. Jurnal Pesona: Jurnal Pendidikan Dasar dan Humaniora, 2(1), 65-72.

Yus, A. (2015). Penilaian Perkembangan Belajar Anak Taman Kanak-kanak. In Penilaian Perkembangan Belajar Anak Taman Kanak-kanak. Jakarta: Kencana Prenada Media Group. Yusuf, A. M. (2009). Ensiklopedia Tematis Ayat Al-Qur'an E Hadist Jilid 4. Jakarta: Widya Cahaya. 